\title{
DNA copy number profiles of gastric cancer precursor lesions
} Tineke E Buffart ${ }^{1}$, Beatriz Carvalho*1,2, Thomas Mons' ${ }^{1}$, Rui M Reis ${ }^{3}$, Cátia Moutinho ${ }^{2}$, Paula Silva², Nicole CT van Grieken¹, Michael Vieth ${ }^{4}$, Manfred Stolte ${ }^{4}$, Cornelis JH van de Velde ${ }^{5}$, Evelin Schrock ${ }^{6}$, Anja Matthaei ${ }^{6}$, Bauke Ylstra1 $^{1}$, Fátima Carneiro ${ }^{2,7}$ and Gerrit A Meijer ${ }^{1}$

Address: ${ }^{1}$ Department of Pathology, VU University Medical Center, Amsterdam, The Netherlands, ${ }^{2}$ Institute of Pathology and Molecular Immunology of University of Porto - IPATIMUP, Porto, Portugal, ${ }^{3}$ Life and Health Sciences Research Institute (ICVS), Health Sciences School, University of Minho, Portugal, ${ }^{4}$ Institute of Pathology, Klinikum Bayreuth, Bayreuth, Germany, ${ }^{5}$ Dept. Surgery, Leiden University Medical Center, Leiden, The Netherlands, ${ }^{6}$ Institute of Clinical Genetics, University of Technology, Dresden, Dresden, Germany and ${ }^{7}$ Faculty of Medicine, University of Porto and Hospital, S. Joao, Porto, Portugal

Email: Tineke E Buffart - t.buffart@vumc.nl; Beatriz Carvalho* - b.carvalho@vumc.nl; Thomas Mons - t.mons@xs4all.nl; Rui M Reis - rreis@ecsaude.uminho.pt; Cátia Moutinho - cmoutinho@ipatimup.pt; Paula Silva - psilva@ipatimup.pt; Nicole CT van Grieken - nct.vangrieken@vumc.nl; Michael Vieth -Vieth.LKPathol@uni-bayreuth.de; Manfred Stolte - pathologie.klinikum-bayreuth@tonline.de; Cornelis JH van de Velde - C.J.H.van_de_Velde@lumc.nl; Evelin Schrock - Evelin.Schrock@mailbox.tu-dresden.de; Anja Matthaei - Anja.matthaei@mailbox.tu-dresden.de; Bauke Ylstra - b.ylstra@vumc.nl; Fátima Carneiro - f.carneiro@ipatimup.pt; Gerrit A Meijer - ga.meijer@vumc.nl

* Corresponding author

\begin{abstract}
Background: Chromosomal instability (CIN) is the most prevalent type of genomic instability in gastric tumours, but its role in malignant transformation of the gastric mucosa is still obscure. In the present study, we set out to study whether two morphologically distinct categories of gastric cancer precursor lesions, i.e. intestinal-type and pyloric gland adenomas, would carry different patterns of DNA copy number changes, possibly reflecting distinct genetic pathways of gastric carcinogenesis in these two adenoma types.

Results: Using a 5K BAC array CGH platform, we showed that the most common aberrations shared by the $1 \mathrm{I}$ intestinal-type and 10 pyloric gland adenomas were gains of chromosomes 9 (29\%), I Iq (29\%) and 20 (33\%), and losses of chromosomes I3q (48\%), 6(48\%), 5(43\%) and 10 (33\%). The most frequent aberrations in intestinal-type gastric adenoma were gains on IIq, $9 \mathrm{q}$ and 8 , and losses on chromosomes $5 q, 6,10$ and 13, whereas in pyloric gland gastric adenomas these were gains on chromosome 20 and losses on $5 q$ and 6 . However, no significant differences were observed between the two adenoma types.

Conclusion: The results suggest that gains on chromosomes $8,9 \mathrm{q}, \mathrm{IIq}$ and 20 , and losses on chromosomes 5q, 6, 10 and 13, likely represent early events in gastric carcinogenesis. The phenotypical entities, intestinal-type and pyloric gland adenomas, however, do not differ significantly $(P=0.8)$ at the level of DNA copy number changes.
\end{abstract}




\section{Background}

Gastric cancer is the second most frequent malignancy worldwide and the prognosis of this malignancy remains very poor [1]. Gastric cancer incidence and mortality rates differ between different countries within the European Union [2]. In the Netherlands it ranks fifth as a cause of cancer death, with approximately 2,200 new cases each year [3]. Surgery with curative intent is the treatment of choice in advanced cases of gastric cancer, whereas local endoscopic mucosectomy can be curative in early gastric cancer. Detection and removal of gastric neoplasias in an early or even premalignant state will contribute to reduce death due to gastric cancer. To achieve this goal, better tests for early detection of gastric cancer are needed, and an improved understanding of the biology of gastric cancer progression is crucial in this respect.

According to the Correa model, pathogenesis of intestinal-type gastric adenocarcinoma follows a pathway of chronic active gastritis due to Helicobacter pylori infection, leading to mucosal atrophy, intestinal metaplasia followed by intraepithelial neoplasia and finally invasive adenocarcinoma [4]. Genetic characterization of tissue samples in intraepithelial neoplasia stage would substantially contribute to our understanding of the molecular pathogenesis of gastric cancer. However, these lesions are only rarely detected, possibly due to rapid progression through this stage towards cancer, and are usually present only in parts of biopsy specimens, hampering genomic analysis of these lesions. Analysis of alternative precursor lesions could therefore, at least partly, be a substitute. Development of gastric cancer through an adenoma stage, although less common, is such alternative route. These adenomas are occasionally detected during gastroscopy and present as large lesions that histologically show intraepithelial neoplasia, which makes them suitable for genomic analysis. Gastric adenomas have a direct malignant potential and account for approximately $20 \%$ of all epithelial polyps $[5,6]$. Gastric adenomas can have a classic tubular, tubulovillous, or villous morphology with a predominantly intestinal-type epithelium, but can also appear as pyloric gland adenomas [6]. Pyloric gland adenomas arise from deep mucoid glands in the stomach and are strongly positive for mucin $6[7,8]$. A substantial number of gastric adenomas already show progression to adenocarcinoma. On first diagnosis around $30-40 \%$ of all pyloric gland adenomas already show a focus of carcinoma $[9,10]$. For intestinal-type adenomas this number is lower and varies from 28,5\% for villous adenomas and $29.4 \%$ for tubulovillous type adenomas to only $5.4 \%$ in the tubular adenomas [11]. Both adenocarcinomas, ex intestinal-type adenomas and ex pyloric gland adenomas, show glandular structures, in contrast to diffuse type gastric cancer.
A key feature in the pathogenesis of most gastric cancers, as in many other solid cancers, is chromosomal instability, resulting in gains and losses of parts or even whole chromosomes [12]. These chromosomal changes can be analyzed by comparative genomic hybridization (CGH). Several previous studies have detected genetic alterations in gastric adenomas using this technique, being gains on chromosome 7q, 8q, 13q, 20q, and losses on chromosome 4p, 5q, 9p 17p and 18q [13-16]. Although uncommon and only observed in adenomas with high grade intraepithelial neoplasia, high level amplifications have been detected on chromosomes 7q, 8p, 13q, 17q and 20q [13-16]. In gastric adenocarcinomas, consistently described chromosomal aberrations are gains on chromosome 3q, 7p, 7q, 8q, 13q, 17q and 20q and losses on chromosome 4q, 5q, 6q, 9p, 17p and 18q. High level amplifications have been repeatedly detected on $7 q, 8 p$, $8 q, 17 q, 19 q$ and 20q [14,17-23]. Yet, chromosomal aberrations, or DNA copy number changes, are not uniform in gastric cancer [24]. Subgroups with different patterns of DNA copy number alterations can be recognized, which have been shown to be associated with clinical outcome as well [25].

In the present study, we set out to study whether two morphologically distinct categories of gastric cancer precursor lesions, i.e. intestinal-type and pyloric gland adenomas, would carry different patterns of DNA copy number changes, possibly reflecting distinct genetic pathways of gastric carcinogenesis in the two adenoma types.

\section{Results}

DNA copy number changes were observed in 10 out of 11 intestinal-type adenomas and 9 out of 10 pyloric gland adenomas. The mean number of chromosomal events, defined as gains and losses, per tumour was 6.0 (range 018 ), including 2.9 (range 0-14) gains and 3.0 (range $0-7$ ) losses. In intestinal-type adenomas, the mean number of chromosomal events per tumour was 6.5 (range $0-18$ ) of which 3.4 (range 0-14) gains and 3.1 (range 0-7) losses, and in the pyloric gland adenomas the mean numbers were 5.4 (range 0-9), 2.4 (range $0-7$ ) and 3.0 (range $0-7$ ) respectively.

In the intestinal-type gastric adenomas, the most common aberrations observed were gains on chromosomes 8 , $9 \mathrm{q}$ and $11 \mathrm{q}$, and losses on chromosomes 5q, 6, 10 and 13 . In four adenomas (36.4\%), gain of chromosome 11q23.3 was observed with a common region of overlap of $2.6 \mathrm{Mb}$. Gain of chromosome $9 \mathrm{q}$ was observed in four adenomas (36.4\%) with a $12.6 \mathrm{Mb}$ common region of overlap located on chromosome 9q33.1-q34.13. Gain of chromosome 8 was observed in three adenomas (31\%), two of which adenomas showed gain of whole chromosome 8 , and the third adenoma showed a gain of chromosome $8 \mathrm{p}$ - 
q22.3 with an additional $28.7 \mathrm{Mb}$ gain on chromosome 8q24.11-qter. In addition, gains were observed on chromosomes 1, 3, 6p, 7, 11p, 12p, 13q, 16, 17, 19, 20 and 22q. No amplifications were seen in the intestinal-type adenomas.

Deletions on chromosome 13 were observed in seven intestinal-type adenomas (64\%). Of these, five showed a 11.9 Mb deletion of chromosome 13q21.2-21.33 with an additional 7.7 Mb deletion on chromosome 13q31.131.3. The other two adenomas showed a $16.6 \mathrm{Mb}$ deletion of 13q14.3-31. A deletion on chromosome 6 was observed in six adenomas (55\%), with an overlapping region of $68.9 \mathrm{Mb}$ located on 6cen-q22.1. A deletion of chromosome $5 \mathrm{q}$ was observed in four adenomas (36\%) with a common region of overlap located on chromosome 5q22.1-q23.2. In addition, a deletion of whole chromosome 10 was observed in four adenomas (36\%). Other losses observed in intestinal-type adenomas were located on chromosomes 8q,9p, 10,12q, 20q and 21. An overview of all DNA copy number aberrations of the intestinal-type adenomas is shown in Table 1.

The most frequent aberration observed in pyloric gland adenomas were gains on chromosome 20 and losses on chromosomes $5 \mathrm{q}$ and 6 . Gains on chromosome 20 were seen in four adenomas (40\%). Three adenomas showed a $9.8 \mathrm{Mb}$ gain of chromosome 20q13.12-q13.33, and gain of whole chromosome 20 was observed in the other adenoma. In addition, gains were seen on chromosomes 1 , $3 \mathrm{q}, 5 \mathrm{q}, 7,9 \mathrm{q}, 11 \mathrm{q}, 12 \mathrm{q}, 13 \mathrm{q}, 15 \mathrm{q}, 17$ and 22q. One pyloric gland adenoma showed amplifications, located on 12q13.2-q21.1 and 20q13.3-q13.33.

Five pyloric gland adenomas (50\%) showed loss of chromosome 5q, two of which had lost a whole chromosome arm, while two adenomas showed a $22.4 \mathrm{Mb}$ deletion of 5q11.2-q13.3 and one adenoma a $40.3 \mathrm{Mb}$ deletion of 5q21.1-q31.2. Loss of chromosome 6 was observed in four pyloric gland adenomas (40\%), three of which showed a complete loss of $6 \mathrm{q}$ and one adenoma showed a 51.2 Mb deletion of 6p21.1-q16.3. Other chromosomal losses were observed on chromosomes $1 \mathrm{p}, 2 \mathrm{q}, 4,9 \mathrm{p}, 10$, $12 q 13 q, 14 q, 16,18 q, 20 q$, and 21. An overview of DNA copy number aberrations of the pyloric gland adenomas is shown in Table 2.

The most common aberrations shared by both intestinaltype and pyloric gland adenomas were gain of chromosome 9q (29\%), 11q (29\%), and 20q (33\%) and loss of chromosome $5(43 \%), 6(48 \%), 10(33 \%)$ and $13 \mathrm{q}$ (48\%). By comparing intestinal-type and pyloric gland adenomas, CGH Multiarray revealed eight clones to be significantly different, six of which were located at chromosome 6q14-q21 ( $\mathrm{p}=0.02$ to 0.05 ) and two clones on chromosome 9p22-p23 ( $\mathrm{p}=0.02$ and 0.04, respectively) (Figure 1). No genes located in the regions covered by these clones have been known to be involved in cancer related biological processes. Yet, CGH Multiarray Region, after correction for multiplicity, yielded a false discovery rate (FDR) of 1 for all these regions, indicating no significant differences between the two different types of adenomas at the chromosomal level. Unsupervised hierarchical cluster analysis yielded 2 clusters. No significant associations were found here $(\mathrm{p}=0.8)$.

\section{Discussion}

Given the heterogeneous phenotype of gastric cancer, the present study primarily aimed to compare copy number changes between intestinal-type adenomas and pyloric gland adenomas, in order to find leads towards genetic pathways involved in the pathogenesis of gastric cancer. Adenoma-to-carcinoma progression is observed in 30$40 \%$ of the pyloric gland adenomas and in approximately $5-30 \%$ of the intestinal-type adenomas (varying from about $5 \%$ in tubular adenomas to almost $30 \%$ for tubulovillous and villous adenomas) [9-11], indicating the direct malignant potential of these two adenoma types and making gastric adenomas a suitable model for detecting early events in gastric carcinogenesis.

Pyloric gland adenomas constitute a recently recognized entity $[8,26]$. To the best of our knowledge, this type of adenomas has never been analyzed by array CGH before. The mean number of events in this type of adenoma was $5.4(0-9)$, with $2.4(0-7)$ gains and $3(0-7)$ losses. This is comparable with the mean number of aberrations in intestinal-type adenomas $(6.5(0-18), 3.4(0-14)$ and 3.1 (0-7) respectively). In pyloric gland adenomas, frequent events were gain on chromosome 20 and losses on chromosomes $5 \mathrm{q}$ and 6 , while intestinal-type adenomas mainly showed gain on chromosomes $8,9 \mathrm{q}$, and $11 \mathrm{q}$, and losses on chromosomes 5q, 6, 10 and 13. In the present study, gain of chromosome 7 was less common than found previously [16]. Although these frequently altered regions differ between the two types of adenomas, hierarchical cluster analyses did not separate the groups. In addition, CGH Multiarray Region did not reveal any significant differences after correction for multiple comparisons. This lack of statistically significant differences could be due to the limited sample size combined with the fact that in general, adenomas show little chromosomal aberrations. On the other hand, it could simply be that these morphologically different entities do not differ in terms of chromosomal gains and losses. Finding no significant differences at the chromosomal level does not preclude other genetic and biological differences such as mutation or promoter methylation status of specific genes. 
Table I: Overview of the DNA copy number changes in II intestinal-type adenomas

\begin{tabular}{|c|c|c|c|c|c|}
\hline \multirow[b]{2}{*}{ Tumour ID } & \multicolumn{2}{|c|}{ Chromosomal aberrations } & \multicolumn{3}{|l|}{ Flanking clones } \\
\hline & Gains & Losses & Segment size (Mb) & Start & End \\
\hline \multirow[t]{7}{*}{ I } & $\mid p-p 36.11$ & & 26.68 & RPII-465B22 & RPI-I59AI9 \\
\hline & & $5 q 13.2-q 23.2$ & 55.26 & RPII-II5I6 & CTB-1054G2 \\
\hline & 6p21.33-p21.1 & & 13.78 & RPII-346K8 & RPII-227E22 \\
\hline & & $6 p 21.1-q 16.1$ & 52.05 & RPII-89II7 & RP3-393DI2 \\
\hline & $9 q 33.1-34.2$ & & 17.32 & RPII-27II & RPII-4I7A4 \\
\hline & $11 \mathrm{q} 23.3$ & & 4.80 & RPII-4N9 & RPII-730KII \\
\hline & & $|3 q 2| .1-q 31.3$ & 39.63 & RPII-200FI5 & RPII-62D23 \\
\hline \multirow[t]{18}{*}{2} & $1 p-1 p 33$ & & 46.90 & RPII-465B22 & RPII-330MI9 \\
\hline & 6p21.33-p21.I & & 14.12 & RPII-346K 8 & RPII-I I IG20 \\
\hline & & $6 p 21.1-q 16.2$ & 54.91 & RPII-554OI4 & RPII-79GI5 \\
\hline & $8 p-q 22.3$ & & 105.67 & GSI-77L23 & RPII-200AI3 \\
\hline & $8 q 24.11-q$ ter & & 28.65 & RPII-278L8 & RP5-I056B24 \\
\hline & $9 q 33.1-q 34.2$ & & 13.63 & RPII-85O2I & RPII-4I7A4 \\
\hline & IIp| I.2-q13.5 & & 31.69 & RPII-58K22 & RPII-30J7 \\
\hline & $11 \mathrm{q} 23.3$ & & 2.62 & RPII-4N9 & RPII-62AI4 \\
\hline & $|2 q| 3.1|-q| 4.1$ & & 10.57 & RPII-493LI 2 & RPII-57IM6 \\
\hline & & $13 q 21.1-q 21.33$ & 18.24 & RPII-200FI5 & RPII-335N6 \\
\hline & & $13 q 31.1-q 31.3$ & 12.49 & RPII-533P8 & RPII-62D23 \\
\hline & $16 p \mid 3.3-q 21$ & & 57.26 & RPII-243KI 8 & RPII-405F3 \\
\hline & & $16 q 21-q 22.1$ & 5.97 & RPII-I05C20 & RPII-298CI5 \\
\hline & $16 q 22.1-q 24.3$ & & 22.46 & RPII-63M22 & CTC-240G 10 \\
\hline & 17 & & 81.24 & GSI-68FI8 & RPII-5670I6 \\
\hline & 19 & & 61.01 & CTB- $1031 \mathrm{Cl} 6$ & GSI-II29C9 \\
\hline & $20 q|| .2|-q| \mid .23$ & & 5.09 & RP3-324017 & RP5-977BI \\
\hline & 20q13.12-qter & & 19.60 & RPI-I38B7 & CTB8IFI2 \\
\hline 3 & - & - & & & \\
\hline \multirow[t]{12}{*}{4} & 6p21.1 & & 3.32 & RPII-79J5 & RPII-I $21 G 20$ \\
\hline & & $6 p \mid 2.3-q 22.1$ & 76.38 & RPII-79G I 2 & RPII-59DI0 \\
\hline & 7 & & 156.89 & RPII-5I0K8 & СТВ-3К 23 \\
\hline & & $8 q 22.3-q 23.3$ & 9.69 & RPII-I42M8 & RPII-26IF23 \\
\hline & $9 q 33.1-q 34.13$ & & 12.58 & RPII-55P2I & RPII-83N9 \\
\hline & I Iq23.3 & & 3.04 & RPII-4N9 & RPII-8KIO \\
\hline & & $13 q 21.2-q 21.33$ & 17.05 & RPII-240M20 & RPII-77P3 \\
\hline & & $13 q 31.1-q 31.3$ & 11.68 & RPII-400M8 & RPII-I00A3 \\
\hline & $16 q 23.2-q 24.3$ & & 8.92 & RPII-303EI6 & RP4-597G I 2 \\
\hline & $20 p-q \mid 3.2$ & & 53.40 & CTB-1061I & RP5-II62C3 \\
\hline & $20 \mathrm{q} / 3.3 \mathrm{I}$-qter & & 8.06 & RP5-II67H4 & CTB-8IFI2 \\
\hline & $22 q$ & & 33.72 & XX-P8708 & CTB-99K 24 \\
\hline 5 & & I2q24.31-qter & 11.75 & RPII-322N7 & RPII-IK22 \\
\hline \multirow[t]{7}{*}{6} & 3 & & 193.37 & RPII-299N3 & RPII-279PIO \\
\hline & & $6 c e n-q 24.1$ & 88.49 & RPII-9IEI7 & RPII-86O4 \\
\hline & 7 & & 156.09 & RPII-5I0K8 & RPII-5|8|I2 \\
\hline & 8 & & 144.26 & RPII-9IJI9 & RP5-I।I8A7 \\
\hline & & $13 q 21.1-q 21.33$ & 11.86 & RPII-640EII & RPI I-452P23 \\
\hline & & $13 q 31.1-q 31.3$ & 9.62 & RPII-400M8 & RPII-306OI \\
\hline & & $20 q|3.2-q| 3.3 \mid$ & 1.41 & RPII-2I2M6 & RP4-586JII I \\
\hline \multirow[t]{3}{*}{7} & & $5 q 21.1$-qter & 80.52 & CTC-I 564E20 & RPII-28IOI5 \\
\hline & & 10 & 132.19 & RPII-29AI9 & RPII-45AI7 \\
\hline & $|3 q 2| .33-3||$. & & 8.76 & RPII-209P2 & RPII-470MI \\
\hline
\end{tabular}


Table I: Overview of the DNA copy number changes in II intestinal-type adenomas (Continued)

\begin{tabular}{|c|c|c|c|c|c|}
\hline \multirow[t]{9}{*}{8} & & $5 q 22.1-q 23.2$ & 13.28 & RPII-2760I8 & RPII-I4L4 \\
\hline & & $6 p \mid 2.3-q 22.1$ & 74.37 & RPII-89|I7 & RPII-I49MI \\
\hline & & 9p21.1-pter & 31.18 & RPII-|47III & RPII-I2KI \\
\hline & & 10 & 133.18 & RPII-IODI3 & RPII-45AI7 \\
\hline & & $|3 q| 4.3-q 3 \mid .3$ & 39.71 & RPII-2IIJII & RPII-3060I \\
\hline & 17 & & 77.65 & GSI-68FI8 & RPII-398J5 \\
\hline & 19 & & 63.31 & CTC-546CII & CTD-3138B 18 \\
\hline & 20 & & 60.87 & RP4-686C3 & RP4-59IC20 \\
\hline & $22 q$ & & 31.25 & XX-bac32 & CTA-722E9 \\
\hline \multirow[t]{10}{*}{9} & & $5 q 14.3-q 23.2$ & 33.06 & RPII-302LI7 & RPII-I4L4 \\
\hline & & $6 p 22.2-q 22.3$ & 8.44 & RPII-9In3 & RPII-88h24 \\
\hline & & $6 p \mid 2.1-q 24.1$ & 88.89 & RPII-7hI6 & RPII-368PI \\
\hline & 8 & & 145.95 & GSI-77L23 & CTC-489DI4 \\
\hline & $9 q 33.1$-qter & & 13.60 & RPII-9IG7 & GSI-I35II7 \\
\hline & & 10 & 133.18 & RPII-IODI 3 & RPII-45AI7 \\
\hline & I I q23.3 & & 3.16 & RPII-4N9 & RPII-2I5DI0 \\
\hline & & 13q14.3-qter & 58.59 & RPII-240M20 & RPII-480K I6 \\
\hline & & $20 q|3.2-q| 3.3 \mid$ & 1.96 & RPII-55EI & RP5-832E24 \\
\hline & & $2 \mid$ cen-q2I. 3 & 17.39 & RPII-193B6 & RPII-4INI9 \\
\hline \multirow[t]{4}{*}{10} & & $8 q 22.3-q 23.3$ & 12.93 & RPII-I42M8 & RPII-I43P23 \\
\hline & & 10 & 134.52 & RPII-IODI3 & RPII-I22KI3 \\
\hline & & |3q2|.|-q21.33 & 18.03 & RPII-322FI8 & RPII-335N6 \\
\hline & & $13 q 31.1-q 31.3$ & 8.99 & RPII-533P8 & RPII-505P2 \\
\hline
\end{tabular}

II

Aberrations already detected in adenomas may be early events in the stepwise process of accumulating changes which may cause progression of adenoma to carcinoma. As expected, the mean number of chromosomal events was lower in adenomas compared to the carcinomas $[13,14,27]$. Moreover, high level amplifications are uncommon in adenomas, while carcinomas frequently show high level amplifications $[13,16]$.

The aberrations found in both intestinal-type and pyloric gland adenomas, such as losses on chromosome $5 \mathrm{q}$, are also frequently detected in gastric carcinomas $[15,19,28]$. Previous CGH results showed a significantly higher number of chromosome $5 \mathrm{q}$ losses in intestinal-type carcinoma compared to diffuse type carcinoma [29]. Chromosome 6 , also lost in both types of adenomas, frequently is deleted in gastric carcinomas as determined by LOH studies [30,31]. Moreover, chromosome 6q deletion has been reported to be involved in an early stage of gastric carcinogenesis, since chromosome $6 \mathrm{q}$ deletions are frequently detected in early gastric cancer and also in intestinal metaplasia [31,32]. Losses of chromosomes 10 and 13 have been previously observed in adenomas at lower frequencies. In gastric carcinomas, both gains and losses of chromosome 10 and 13 have been observed by previous CGH studies $[15,19,21,33]$. Chromosome 10 harbors the oncogene FGFR2 (10q26) and tumour suppressor genes PTEN/ MMAC1 (10q23) and DMBT1 (10q25-q26), both involved in carcinogenesis, which could explain the observation of both gains and losses of chromosomes 10 in gastric carcinomas [34-36]. Indeed chromosome 13 harbors tumour suppressor genes such as BRCA2 (13q12.3) and retinoblastoma gene (RB1) (13q14). In contrast, gain of chromosome $13 \mathrm{q}$ has been correlated to colorectal adenoma-to-carcinoma progression, and amplification of chromosome 13 has been observed in gastric adenomas with severe intraepithelial neoplasia $[14,37]$. The precise role of chromosome 13 aberration in gastric cancer therefore remains to be resolved.

Most frequent copy number gains were observed on chromosomes 8, 9q, 11q and 20. Especially gains of chromosomes 8 and 20 are consistent with previous (array) CGH studies in both gastric adenomas and gastric carcinomas [13-16,19,25], implicating this as early events in tumourigenesis. Although gain of chromosome 11q has not been described as a frequent event in adenomas, in carcinomas gain or amplification on chromosome $11 \mathrm{q}$ is common [13-16]. In the present study gain of chromosome $11 \mathrm{q}$ was frequently observed in the adenomas, implying the malignant potential of these adenomas.

\section{Conclusion}

These data indicate that gains on chromosomes $8,9 q, 11 q$ and 20 and losses on chromosomes 5q, 6, 10 and 13 are early events in gastric carcinogenesis. Despite the pheno- 
Table 2: Overview of the DNA copy number changes in 10 pyloric gland adenomas

\begin{tabular}{|c|c|c|c|c|c|}
\hline \multirow[b]{2}{*}{ Tumour ID } & \multicolumn{2}{|l|}{ Chromosomal aberrations } & \multicolumn{3}{|l|}{ Flanking clones } \\
\hline & Gains & Losses & Segment size $(\mathrm{Mb})$ & Start & End \\
\hline \multirow[t]{8}{*}{12} & |q21.3-q23.3 & & 9.95 & RPII-98DI8 & RPII-5K23 \\
\hline & $1 q 42.13-q 43$ & & 14.07 & RPII-375H24 & RPII-80B9 \\
\hline & $3 q$ & & 111.59 & $\mathrm{RPII-3I2HI}$ & RPII-23M2 \\
\hline & $5 q 35.1-q 35.3$ & & 9.11 & RPII-20O22 & RPII-45IH23 \\
\hline & & $6 q$ & 115.76 & RPII-524HI9 & RP5-I086L22 \\
\hline & 7 & & 156.09 & RPII-5I0K8 & RPII-5I8II2 \\
\hline & 17 & & 77.48 & RPII-4F24 & RPII-3I3FI5 \\
\hline & 20 & & 63.47 & CTB-1061I & CTB-8IFI2 \\
\hline 13 & - & - & & & \\
\hline \multirow[t]{5}{*}{14} & & 4 & 191.13 & CTC-963K6 & RPII-45F23 \\
\hline & & $5 q$ & 128.59 & CTD-2276O24 & RPII-28IOI5 \\
\hline & & $14 q$ & 83.81 & RPII-98N22 & RPII-73MI8 \\
\hline & & 16 & 89.71 & RPII-344L6 & RP4-597G I 2 \\
\hline & $20 q|3.2-q| 3.33$ & & 10.84 & RP4-724EI6 & CTB-8IFI2 \\
\hline \multirow[t]{5}{*}{15} & $9 q 33.2-q 34.3$ & & 16.81 & RPII-57KI & RPII-83N9 \\
\hline & II q23.2-q24.3 & & 16.04 & RPII-635FI2 & RPII-567M2I \\
\hline & $12 q 14.3-q 15$ & & 2.58 & RPII-30III & RPII-444B24 \\
\hline & $20 q|3.3|-q \mid 3.33$ & & 6.86 & RP5-II53D9 & RP5-963E22 \\
\hline & $22 q$ & & 32.53 & XX-p8708 & CTA-722E9 \\
\hline \multirow[t]{5}{*}{16} & $9 q 33.3$-qter & & 13.57 & RPII-85C2I & GSI-I35II7 \\
\hline & & I0pI2.I-qter & 110.28 & RPII-379L2I & RPII-45AI7 \\
\hline & I I q23.1-q24.3 & & 17.72 & RPII-I07PIO & RPII-567M2I \\
\hline & & $13 q 31.1-q 32.1$ & 10.84 & RPII-66IDI7 & RPII-40HIO \\
\hline & & $20 q|3.2-q| 3.3 \mid$ & 1.96 & RPII-55EI & RP4-586JII \\
\hline \multirow[t]{9}{*}{17} & & Ip34.3-pter & 35.59 & RPI-37JI8 & RPII-204L3 \\
\hline & Ip33-qter & & 203.62 & RP4-739HII & RPII-55IG24 \\
\hline & & $2 q 31.1$-qter & 66.00 & RPII-205BI9 & RPII-556HI7 \\
\hline & & $5 q 21.1-q 31.2$ & 40.27 & CTD-2068CII & RPII-5I5CI6 \\
\hline & $5 q 31.3$-qter & & 39.06 & CTD-2323HI2 & RPII-45IH 23 \\
\hline & & $6 q$ & 113.61 & RPII-89D6 & CTB-57H24 \\
\hline & & 10 & 134.52 & RPII-IODI3 & RPII-I22KI3 \\
\hline & & |3q31.1-qter & 36.14 & RPII-388E20 & RPII-245BII \\
\hline & & $20 \mathrm{ql} 3.2$-qter & 11.24 & RPII-I5MI5 & RP5-I022E24 \\
\hline \multirow[t]{7}{*}{18} & & $5 q \mid 1.2-q 21.2$ & 51.24 & CTC-I329HI4 & RPI-66PI9 \\
\hline & & $6 p \mid 2.1-q 16.3$ & 51.24 & RPII-7HI6 & RPII-438N24 \\
\hline & & 9 pter-q13 & 66.82 & GSI-4ILI3 & RPII-265B8 \\
\hline & & 10 & 133.04 & RPII-IODI3 & RPII-45AI7 \\
\hline & & $13 q 21.1-q 21.33$ & 18.39 & RPII-240M20 & RPII-335N6 \\
\hline & & $13 q 31.1-q 31.3$ & 12.45 & RPII-55ID9 & RPII-I00A3 \\
\hline & & 2 Icen-q2I.3 & 17.39 & RPII-I93B6 & RPII-4INI9 \\
\hline \multirow[t]{6}{*}{19} & & Ip32.3-p21.I & 50.40 & RPII-II7D22 & RP5-II08MI7 \\
\hline & & $5 q|| .2-q \mid 3.3$ & 24.64 & RP4-592PI8 & CTD-2200O3 \\
\hline & $|3 q| 2.1|-q| 4.3$ & & 31.58 & RPII-187L3 & RPII-327P2 \\
\hline & $15 q 12-q 26.3$ & & 77.21 & RPII-|3|I|2| & CTB-I54PI \\
\hline & & $18 q 21.1-q 23$ & 31.31 & RPII-46DI & RPII-I54HI2 \\
\hline & $22 q 13.2-q$ ter & & 10.02 & CTA-229A8 & CTA-799FI0 \\
\hline \multirow[t]{2}{*}{20} & & $9 p-q 13$ & 66.57 & GSI-4ILI3 & RPII-274BI 8 \\
\hline & I2q13.2-q2I.I (amplification) & & 19.50 & RPII-548L8 & RPII-255II4 \\
\hline
\end{tabular}


Table 2: Overview of the DNA copy number changes in 10 pyloric gland adenomas (Continued)

\begin{tabular}{|c|c|c|c|c|c|}
\hline & & $12 q 21.2$-qter & 55.56 & RPII-25]3 & RPII-IK22 \\
\hline & & $|8 q 2| .3 \mid-q 23$ & 23.28 & RPII-383D22 & СТС-964M9 \\
\hline & 20q|3.|3-q|3.33 (amplification) & & 14.62 & RP5- $104 I C I 0$ & RP5-I022E24 \\
\hline \multirow[t]{4}{*}{21} & $5 p$ & & 43.15 & CTD-2265D9 & RPII-2819 \\
\hline & & $5 q$ & 130.26 & RPII-269M20 & RPII-45IH23 \\
\hline & $6 p$ & & 62.57 & CTB-62III & RPII-506N2I \\
\hline & & $6 q$ & 106.73 & RPII-767JI4 & RP5-I086L22 \\
\hline
\end{tabular}

typical differences, intestinal-type and pyloric gland adenoma do not differ significantly at the level of DNA copy number changes.

\section{Methods \\ Material}

Twenty-one paraffin-embedded gastric adenomas, 11 intestinal-type and 10 pyloric gland adenomas, were included in this study (Figure 2A and 2B). Tumour and patient data are given in Table 3 . For each case, a tumour area consisting for at least $70 \%$ of tumour cells was demarcated on a $4 \mu \mathrm{m}$ hematoxylin and eosin stained tissue section. Adjacent 10-15 serial tissue sections of $10 \mu \mathrm{m}$ were stained with hematoxylin and the corresponding tumour area was microdissected using a surgical blade. A final $4 \mu \mathrm{m}$ "sandwich" section was made and stained with hemotoxylin and eosin, to compare with the first slide as a control. After deparaffinization, DNA was extracted by a column-based method (QIAamp DNA mini kit; Qiagen, Westburg, Leusden, NL) [38].

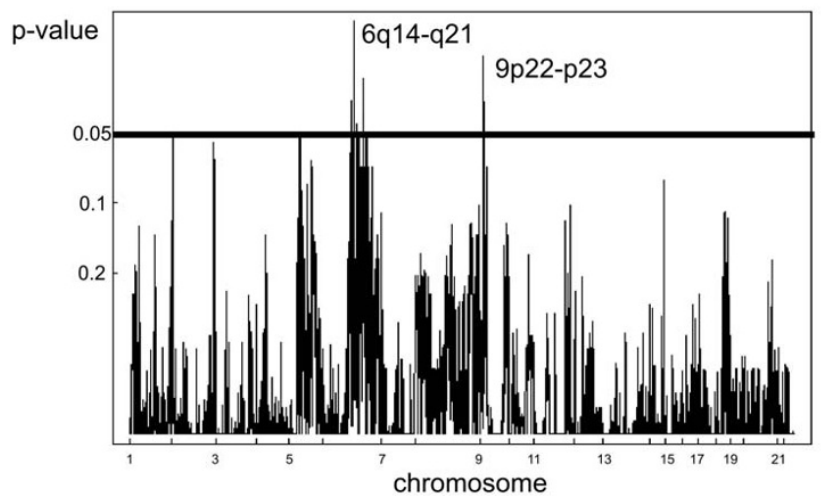

Figure I

Comparison of DNA copy number alterations in intestinal and pyloric gland type gastric adenomas. A p-value ( $Y$-axis) was calculated for every clone, based on a Wilcoxon test with ties, and plotted in chromosomal order from chromosome I to 22 (X-axis). Eight clones reached the level of significance $(p<0.05)$, but failed to maintain a significantly low false discovery rate after correction for multiple comparison.
Genomic DNA obtained from peripheral blood from ten normal individuals was pooled (either ten females or ten males, depending on the gender of the patient from which the adenoma was obtained) and used as control reference DNA.

\section{Array CGH}

Array CGH was performed essentially as described previously [39]. Briefly, 300 ng tumour and reference DNAs, sex-mismatch as experimental control, were labelled by random priming (Bioprime DNA Labelling System, Invitrogen, Breda, NL), each in a volume of $50 \mu \mathrm{L}$. Non incorporated nucleotides were removed using ProbeQuant G50 microcolumns (Amersham Biosciences). Cy3 labelled test genomic DNA and Cy5 labelled reference DNA were combined and co-precipitated with $100 \mu \mathrm{g}$ of human Cot1 DNA (Invitrogen, Breda, NL) by adding 0.1 volume of 3 $M$ sodium acetate ( $\mathrm{pH} 5.2$ ) and 2.5 volumes of ice-cold $100 \%$ ethanol. The precipitate was collected by centrifugation at 14,000 rpm for 30 minutes at $4{ }^{\circ} \mathrm{C}$, and dissolved in $130 \mu \mathrm{l}$ hybridization mixture containing 50\% formamide, $2 \times$ SCC and 4\% SDS. The hybridization solution was heated for 10 minutes at $73^{\circ} \mathrm{C}$ to denature the DNA, followed by $60-120$ minutes incubation at $37^{\circ} \mathrm{C}$ to allow the Cot-1 DNA to block repetitive sequences. The mixture was hybridized on an array containing approximately 5000 clones spotted in triplicate and spread along the whole genome with an average resolution of $1.0 \mathrm{Mb}$. The clones are comprised of the Sanger BAC clone set with an average resolution along the whole genome of $1.0 \mathrm{Mb}$ [40], the OncoBac set [41], and selected clones of interest, obtained from the Children's Hospital Oakland Research Institute (CHORI). The selected clones comprise a collection of BAC clones on chromosome 6 filling the gaps larger than $1 \mathrm{Mb}$, and full-coverage contigs on specific regions on chromosomes 8,13 and 20 . Hybridization was performed in a in a hybridization station (Hybstation 12 Perkin Elmer Life Sciences, Zaventem, BE) and incubated for $38 \mathrm{~h}$ at $37^{\circ} \mathrm{C}$. After hybridization, slides were washed in a solution containing 50\% formamide, $2 \times$ SCC, $\mathrm{pH} 7$ for 3 minutes at $45^{\circ} \mathrm{C}$, followed by 1 minute wash steps at room temperature with $\mathrm{PN}$ buffer (PN: $0.1 \mathrm{M}$ sodiumphosphate, $0.1 \%$ nonidet $\mathrm{P} 40, \mathrm{pH} 8), 0.2 \times$ SSC, $0.1 \times$ SCC and $0.01 \times$ SCC. 
Table 3: Tumour and patient information

\begin{tabular}{|c|c|c|c|c|c|c|c|c|c|}
\hline $\begin{array}{c}\text { Tumour } \\
\text { ID }\end{array}$ & $\begin{array}{c}\text { Adenoma } \\
\text { type }\end{array}$ & $\begin{array}{l}\text { Grade of } \\
\text { dysplasia }\end{array}$ & Gender & Age & $\underset{\text { ID }}{\text { Tumour }}$ & $\begin{array}{c}\text { Adenoma } \\
\text { type }\end{array}$ & $\begin{array}{l}\text { Grade of } \\
\text { dysplasie }\end{array}$ & Gender & Age \\
\hline I & Intestinal & Moderate & Male & 75 & 12 & Pyloric gland & Moderate & Male & 78 \\
\hline 2 & Intestinal & Moderate & Male & 45 & 13 & Pyloric gland & Mild & Male & 50 \\
\hline 3 & Intestinal & Moderate & Male & 80 & 14 & Pyloric gland & Severe & Female & 76 \\
\hline 4 & Intestinal & Moderate & Male & 79 & 15 & Pyloric gland & Moderate & Female & 85 \\
\hline 5 & Intestinal & Moderate & Male & 76 & 16 & Pyloric gland & Moderate & Male & 63 \\
\hline 6 & Intestinal & Moderate & Male & 75 & 17 & Pyloric gland & Mild & Female & 86 \\
\hline 7 & Intestinal & Mild & Male & 57 & 18 & Pyloric gland & Moderate & Female & 59 \\
\hline 8 & Intestinal & Moderate & Male & 64 & 19 & Pyloric gland & Moderate & Male & 69 \\
\hline 9 & Intestinal & Mild & Male & 63 & 20 & Pyloric gland & Moderate & Female & 78 \\
\hline 10 & Intestinal & Mild & Male & 75 & 21 & Pyloric gland & Moderate & Male & $?$ \\
\hline 11 & Intestinal & Moderate & Female & 45 & & & & & \\
\hline
\end{tabular}

\section{Image acquisition and data analysis}

Images of the arrays were acquired by scanning (Agilent DNA Microarray scanner- Agilent technologies, Palo Alto, USA) and quantification of the signal and background intensities for each spot for the two channels Cy3 and Cy5 was performed by Imagene 5.6 software (Biodiscovery Ltd, Marina del Rey, CA, USA). Local background was subtracted from the signal median intensities and tumours to reference ratios were calculated. The ratios were normalized against the mode of the ratios of all autosomes. Clones with poor quality of one of the triplicates and hybridization with a standard deviation (SD) $\leq 0.22$ and clones with $>50 \%$ missing values in all adenomas were excluded, leaving 4648 clones for further analysis. All subsequent analyses were done considering the clone position from the UCSC May2004 freeze of the Human Golden Path.

Array CGH smooth $[42,43]$, was used for automated detection of breakpoints to determine copy number gains
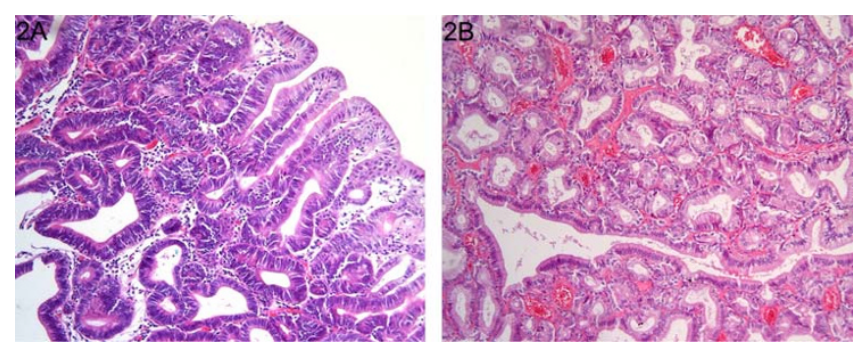

Figure 2

Haematoxilin and eosin staining (original magnification $\times 400$ ) of intestinal-type $(A)$ and pyloric gland $(B)$ gastric adenomas. A. Intestinal-type adenoma of the stomach composed of irregularly arranged glands composed of intestinal-type epithelium with eosinophilic cytoplasm and enlarged nuclei. B. Pyloric gland adenoma of the stomach composed of densely back to back packed glands consisting of cells with pale cytoplasm and small round hyperchromatic nuclei. and losses. Since variation in quality is observed in DNA obtained from formalin-fixed paraffin-embedded gastric tissues, different smoothing parameters were applied, depending on the quality of the hybridization. For array CGH profiles with a standard deviation smaller or equal to 0.15 , between 0.15 and 0.20 or between 0.20 and 0.22 , the applied smoothing parameters to determine gains and losses were $0.10,0.15$ and 0.20 respectively. $\log _{2}$ tumour to reference ratio above 1 was regarded as amplification.

\section{Statistical analysis}

Unsupervised hierarchical cluster analysis was performed to analyze the distributions of the genomic profiles of all adenomas using TMEV software 3.0.3 [44]. Based on normalized smoothed $\log _{2}$ tumour to normal fluorescence intensity ratios, a hierarchical tree was constructed using the parameters complete linkage and euclidean distance. Pearson Chi-square test was used for analyzing correlations between cluster membership and adenoma type (SPSS 11.5.0 for windows, SPSS Inc, Chicago, IL, USA). Pvalues less than 0.05 were considered to be significant.

Supervised analysis was used for identifying chromosomal regions specific for the two adenoma types using CGH Multiarray and CGH Multiarray Region $[45,46]$. Based on normalized smoothed $\log _{2}$ tumour to normal fluorescence intensity ratios, p-values were calculated for the significance of difference of values for each clone between pyloric gland and intestinal-type adenomas, using a Wilcoxon test with ties. To correct for multiple testing, a permutation-based false discovery rate (FDR) was calculated [47].

\section{Competing interests}

The author(s) declares that there are no competing interests. 


\section{Authors' contributions}

TB performed all the data analysis and wrote the manuscript. BC helped with data analysis and writing of the manuscript and helped in coordinating the study. TM performed the DNA isolations and TM and RR performed the array CGH experiments. CM and PS helped with the DNA isolations. NG revised the adenomas derived from Germany. MV and MS provided the material obtained from Germany. CV was involved in reviewing the manuscript and supervision of the study. ES and AM were involved in development and establishing the BAC arrays. BY was involved in development of the BAC arrays and provided the facilities for the microarray experiments. FC provided the material obtained form Portugal, conceived the study and was involved in critically reviewing the manuscript. GM revised the material obtained from Portugal, coordinated the study and helped to draft the manuscript. All authors read and approved the manuscript.

\section{Acknowledgements}

We thank the Mapping Core and Map Finishing groups of the Wellcome Trust Sanger Institute for initial clone supply and verification. This work was financially supported by the Portuguese Foundation for Science and Technology (FCT), grant POCTI/CBO/4I I 79/200I and by Dutch Cancer Society grant-KWF 2004-305I.

\section{References}

I. Parkin DM, Pisani P, Ferlay J: Global cancer statistics. CA Cancer J Clin 1999, 49:33-64, I.

2. Black RJ, Bray F, Ferlay J, Parkin DM: Cancer incidence and mortality in the European Union: cancer registry data and estimates of national incidence for 1990. Eur J Cancer 1997, 33: $1075-1107$

3. Visser O, Coebergh J, Schouten L, Dijck J: Incidence of Cancer in The Netherlands 1997. Utrecht 200I.

4. Correa P, Haenszel W, Cuello C, Tannenbaum S, Archer M: A model for gastric cancer epidemiology. Lancet 1975, 2:58-60.

5. Oberhuber G, Stolte M: Gastric polyps: an update of their pathology and biological significance. Virchows Arch 2000, 437:581-590.

6. Stolte M, Sticht T, Eidt S, Ebert D, Finkenzeller G: Frequency, location, and age and sex distribution of various types of gastric polyp. Endoscopy 1994, 26:659-665.

7. Borchard F, Ghanei A, Koldovski U, Hengels KJ, Buckmann FW: Gastrale Differenzierung in Adenomen der Magenschleim. Immunohistochemische und elektronmikroskopische Untersuchen. Verh Dtsch Ges Pathol 1990, 74:528-524.

8. Hamilton SR, Aaltonen LS: WHO Classification. Tumors of the gastrointestinal tract. Pathology and genetics. IARC Press, Lyon 2000:--20.

9. Stolte $\mathrm{M}$ : Clinical consequences of the endoscopic diagnosis of gastric polyps. Endoscopy 1995, 27:32-37.

10. Vieth M, Kushima R, Borchard F, Stolte M: Pyloric gland adenoma: a clinico-pathological analysis of $\mathbf{9 0}$ cases. Virchows Arch 2003, 442:3|7-32I.

II. Schmitz JM, Stolte M: Gastric polyps as precancerous lesions. Gastrointest Endosc Clin N Am 1997, 7:29-46.

12. Lengauer C, Kinzler KW, Vogelstein B: Genetic instabilities in human cancers. Nature 1998, 396:643-649.

13. Kim YH, Kim NG, Lim JG, Park C, Kim H: Chromosomal alterations in paired gastric adenomas and carcinomas. Am J Pathol 200I, I 58:655-662.

14. Kokkola A, Monni O, Puolakkainen P, Nordling S, Haapiainen R, Kivilaakso E, Knuutila S: Presence of high-level DNA copy number gains in gastric carcinoma and severely dysplastic adenomas but not in moderately dysplastic adenomas. Cancer Genet Cytogenet 1998, 107:32-36.
15. van Dekken H, Alers JC, Riegman PH, Rosenberg C, Tilanus HW, Vissers K: Molecular cytogenetic evaluation of gastric cardia adenocarcinoma and precursor lesions. Am J Pathol 200I, I 58: $1961-1967$

16. Weiss MM, Kuipers EJ, Postma C, Snijders AM, Stolte M, Vieth M, Pinkel D, Meuwissen SG, Albertson D, Meijer GA: Genome wide array comparative genomic hybridisation analysis of premalignant lesions of the stomach. Mol Pathol 2003, 56:293-298.

17. Kimura Y, Noguchi T, Kawahara K, Kashima K, Daa T, Yokoyama S: Genetic alterations in 102 primary gastric cancers by comparative genomic hybridization: gain of $20 \mathrm{q}$ and loss of $18 \mathrm{q}$ are associated with tumor progression. Mod Pathol 2004, 17:1328-1337.

18. Koo SH, Kwon KC, Shin SY, Jeon YM, Park JW, Kim SH, Noh SM: Genetic alterations of gastric cancer: comparative genomic hybridization and fluorescence In situ hybridization studies. Cancer Genet Cytogenet 2000, I I 7:97-103.

19. Sakakura C, Mori T, Sakabe T, Ariyama Y, Shinomiya T, Date K, Hagiwara A, Yamaguchi T, Takahashi T, Nakamura Y, Abe T, Inazawa J: Gains, losses, and amplifications of genomic materials in primary gastric cancers analyzed by comparative genomic hybridization. Genes Chromosomes Cancer 1999, 24:299-305.

20. Takada H, Imoto I, Tsuda H, Sonoda I, Ichikura T, Mochizuki H, Okanoue T, Inazawa J: Screening of DNA copy-number aberrations in gastric cancer cell lines by array-based comparative genomic hybridization. Cancer Sci 2005, 96: I00-1 I0.

21. van Grieken NC, Weiss MM, Meijer GA, Hermsen MA, Scholte GH, Lindeman J, Craanen ME, Bloemena E, Meuwissen SG, Baak JP, Kuipers E): Helicobacter pylori-related and -non-related gastric cancers do not differ with respect to chromosomal aberrations. J Pathol 2000, 192:30I-306.

22. Weiss MM, Kuipers EJ, Hermsen MA, van Grieken NC, Offerhaus J, Baak JP, Meuwissen SG, Meijer GA: Barrett's adenocarcinomas resemble adenocarcinomas of the gastric cardia in terms of chromosomal copy number changes, but relate to squamous cell carcinomas of the distal oesophagus with respect to the presence of high-level amplifications. I Pathol 2003, 199:157-165

23. Wu CW, Chen GD, Fann CS, Lee AF, Chi CW, Liu JM, Weier U, Chen JY: Clinical implications of chromosomal abnormalities in gastric adenocarcinomas. Genes Chromosomes Cancer 2002, 35:2|9-23|.

24. Buffart T, Carvalho B, Hopmans E, Brehm V, Kranenbarg EK, SchaaijVisser T, Eijk P, van Grieken N, Ylstra B, van de Velde CJ, Meijer G: Gastric cancers in young and elderly patients show different genomic profiles. J Pathol 2007, 21 I:45-5I.

25. Weiss MM, Kuipers E], Postma C, Snijders AM, Pinkel D, Meuwissen SG, Albertson D, Meijer GA: Genomic alterations in primary gastric adenocarcinomas correlate with clinicopathological characteristics and survival. Cell Oncol 2004, 26:307-3I7.

26. Kushima R, Ruthlein HJ, Stolte M, Bamba M, Hattori T, Borchard F: 'Pyloric gland-type adenoma' arising in heterotopic gastric mucosa of the duodenum, with dysplastic progression of the gastric type. Virchows Arch 1999, 435:452-457

27. Weiss MM, Kuipers EJ, Postma C, Snijders AM, Siccama I, Pinkel D, Westerga J, Meuwissen SG, Albertson DG, Meijer GA: Genomic profiling of gastric cancer predicts lymph node status and survival. Oncogene 2003, 22: 1872-1879.

28. Oga A, Kong G, Ishii Y, Izumi H, Park CY, Sasaki K: Preferential loss of 5q 14-2I in intestinal-type gastric cancer with DNA aneuploidy. Cytometry 200I, 46:57-62.

29. Wu MS, Chang MC, Huang SP, Tseng CC, Sheu JC, Lin YW, Shun CT, Lin MT, Lin JT: Correlation of histologic subtypes and replication error phenotype with comparative genomic hybridization in gastric cancer. Genes Chromosomes Cancer 200I, 30:80-86.

30. Carvalho B, Seruca R, Carneiro F, Buys CH, Kok K: Substantial reduction of the gastric carcinoma critical region at $6 \mathrm{q} / 6.3$ q23.I. Genes Chromosomes Cancer 1999, 26:29-34.

31. Queimado L, Seruca R, Costa-Pereira A, Castedo S: Identification of two distinct regions of deletion at $6 \mathrm{q}$ in gastric carcinoma. Genes Chromosomes Cancer 1995, 14:28-34.

32. Li BC, Chan WY, Li CY, Chow C, Ng EK, Chung SC: Allelic loss of chromosome 6q in gastric carcinoma. Diagn Mol Pathol 2003, I 2:193-200.

33. Peng DF, Sugihara H, Mukaisho K, Tsubosa Y, Hattori T: Alterations of chromosomal copy number during progression of diffuse- 
type gastric carcinomas: metaphase- and array-based comparative genomic hybridization analyses of multiple samples from individual tumours. J Pathol 2003, 201:439-450.

34. Katoh M, Katoh M: FGFR2 and WDRI I are neighboring oncogene and tumor suppressor gene on human chromosome I0q26. Int J Oncol 2003, 22: I I55-| I59.

35. Mori M, Shiraishi T, Tanaka S, Yamagata M, Mafune K, Tanaka Y, Ueo $H$, Barnard GF, Sugimachi K: Lack of DMBTI expression in oesophageal, gastric and colon cancers. $\mathrm{Br} J$ Cancer 1999, 79:2II-2I3.

36. Wang JY, Huang TJ, Chen FM, Hsieh MC, Lin SR, Hou MF, Hsieh JS: Mutation analysis of the putative tumor suppressor gene PTEN/MMACI in advanced gastric carcinomas. Virchows Arch 2003, 442:437-443.

37. Hermsen M, Postma C, Baak J, Weiss M, Rapallo A, Sciutto A, Roemen G, Arends JW, Williams R, Giaretti W, De Goeij A, Meijer G: Colorectal adenoma to carcinoma progression follows multiple pathways of chromosomal instability. Gastroenterology 2002, I 23: I 109-1 I I9.

38. Weiss MM, Hermsen MA, Meijer GA, van Grieken NC, Baak JP, Kuipers EJ, van Diest PJ: Comparative genomic hybridisation. Mol Pathol 1999, 52:243-25I.

39. Snijders AM, Nowak N, Segraves R, Blackwood S, Brown N, Conroy J, Hamilton G, Hindle AK, Huey B, Kimura K, Law S, Myambo K, Palmer J, Ylstra B, Yue JP, Gray JW, Jain AN, Pinkel D, Albertson DG: Assembly of microarrays for genome-wide measurement of DNA copy number. Nat Genet 200I, 29:263-264.

40. ensembl 2007 [http://www.ensembl.org/Homo sapiens/cytoview]

4l. informa 2007 [http://informa.bio.caltech.edu/Bac onc.html].

42. Jong K, Marchiori E, van der Vaart AV, Ylstra B, Weiss MM, Meijer G: Chromosomal breakpoint detection in human cancer. In LNCN 2003, 26 I I:54-65.

43. Jong K, Marchiori E, Meijer G, Vaart AV, Ylstra B: Breakpoint identification and smoothing of array comparative genomic hybridization data. Bioinformatics 2004, 20:3636-3637.

44. tigr 2007 [http://www.tigr.org/software].

45. CGH Multiarray 2007 [http://www.few.vu.nl/ mavdwiel/].

46. van de Wiel MA, Smeets SJ, Brakenhoff RH, Ylstra B: CGHMultiArray: exact $P$-values for multi-array comparative genomic hybridization data. Bioinformatics 2005, 21 1:3193-3194.

47. Manduchi E, Grant GR, McKenzie SE, Overton GC, Surrey S, Stoeckert C] Jr.: Generation of patterns from gene expression data by assigning confidence to differentially expressed genes. Bioinformatics 2000, 16:685-698.

\section{Publish with Bio Med Central and every scientist can read your work free of charge}

"BioMed Central will be the most significant development for disseminating the results of biomedical research in our lifetime. "

Sir Paul Nurse, Cancer Research UK

Your research papers will be:

- available free of charge to the entire biomedical community

- peer reviewed and published immediately upon acceptance

- cited in PubMed and archived on PubMed Central

- yours - you keep the copyright 